
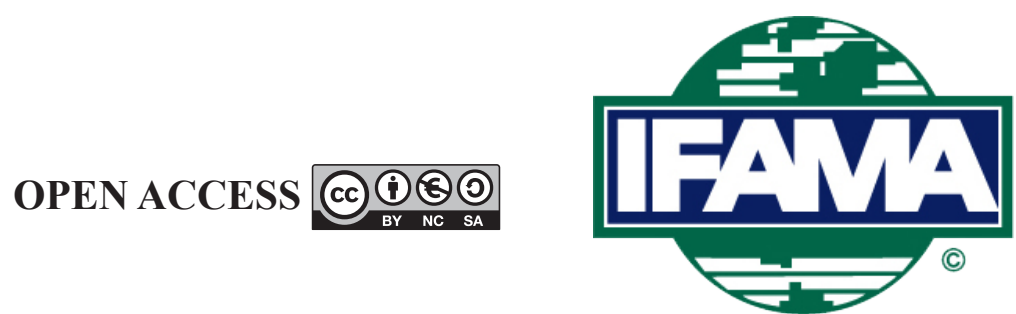

International Food and Agribusiness Management Review

Volume 21 Issue 8, 2018; DOI: 10.22434/IFAMR2017.0066

Received: 15 July 2017 / Accepted: 22 April 2018

\title{
German dairy farmers' attitudes toward farm animal welfare and their willingness to participate in animal welfare programs: a cluster analysis
}

\section{RESEARCH ARTICLE}

\author{
Heinke Heise ${ }^{\oplus a}$ and Ludwig Theuvsen ${ }^{b}$ \\ ${ }^{a}$ Professor and Head of the Chair Management in Agribusiness, and ${ }^{b}$ Post Doc, Georg-August- \\ University of Goettingen, Department of Agricultural Economics and Rural Development, Chair: \\ Management in Agribusiness, Platz der Göttinger Sieben 5, 37073 Goettingen, Germany
}

\begin{abstract}
Farm animal welfare (FAW) is at the center of a controversial public debate, and the demand for higher farm animal welfare standards is growing. Nevertheless, there are hardly any dairy products from pure animal welfare programs (AWPs) on the market. Although dairy farmers are a very important stakeholder group for the successful implementation of AWPs, very little is known about their attitudes toward the introduction of such programs. For this study, 258 conventional dairy farmers in Germany were questioned about FAW and AWPs via an online survey. We identified five clusters (farmer groups) that significantly differ with regard to their attitudes toward AWPs, FAW, and their own willingness to improve the level of animal welfare or take part in specialized AWPs. Cluster A consists of farmers who strongly oppose AWPs; farmers in this cluster will probably not take part in AWPs, especially because they do not consider it profitable to do so. Farmers in cluster B also view AWPs and the associated market effects with some skepticism; however, they are willing to improve their level of animal welfare and, therefore, may someday become willing to participate in AWPs. Cluster C farmers have diverse attitudes toward AWPs; since they are slightly willing to improve the level of animal welfare on their farms and as they are comparatively most optimistic concerning the market effects of higher animal welfare standards, these farmers could also become AWP participants in the future. Farmers in cluster D have positive attitudes toward AWPs and show the highest willingness among the five clusters to improve animal welfare on their farms. However, when it comes to the market effects of higher national animal welfare standards and the market potential for more animal-friendly products, these farmers are the most skeptical; if the economic security of AWPs were guaranteed, Cluster D farmers would probably constitute an important target group. Farmers in cluster E have positive attitudes toward AWPs, show a high willingness to improve the own FAW, and tend to be less skeptical about the market effects of higher animal welfare standards; these farmers constitute the most important potential target group for AWPs. Our results can provide a starting point for the design of tailor-made AWPs that fulfill the requirements of both dairy farmers and the broader public.
\end{abstract}

Keywords: animal welfare program, cluster analysis, dairy farming, farm animal welfare, farmer survey JEL code: Q01, Q10, Q13

(1)Corresponding author: hheise@gwdg.de 


\section{Introduction}

The topic of farm animal welfare (FAW) has attracted growing attention, not only in the media and among the broader public but also in political discussions (Keeling et al., 2013; Lusk and Norwood, 2012; Nocella et al., 2010). Reports from several EU member states reveal the need to improve welfare standards for farm animals in conventional production systems in order for livestock farming to regain social acceptance (EC, 2006; Miele et al., 2013; WBA, 2015). Public criticism is focusing increasingly on certain issues in dairy production, including animal health, the short life expectancy of dairy cows, the high milk yields demanded per cow, lack of outdoor access and pasturing, and practices that are seen as cruel and unnatural, such as dehorning (Boogard et al., 2010; Busse, 2015; Weinrich et al., 2014).

In response to the continuing public debate on FAW, some animal welfare programs (AWPs) that market products of animal origin produced under higher animal welfare standards have emerged on the market in several EU member states. But so far, existing AWPs (in the form of voluntary labels or industry initiatives without labelling) concentrate on higher animal welfare requirements for poultry and pig production. In Germany, for instance, there is currently no dedicated AWP for dairy farming that addresses all publicly debated animal welfare issues. However, there are programs that successfully market pasture-raised milk. Hellberg-Bahr et al. (2012) showed that there is a high willingness to pay a price premium for pasture-raised milk among German consumers, who associate pasturing with higher animal welfare standards and more sustainable milk production (Heerwagen et al., 2013; Hellberg-Bahr et al., 2012; Weinrich et al., 2014). These findings indicate an interesting market potential for more animal welfare friendly dairy products.

Dairy farmers currently face major challenges due to the high volatility of milk prices and strong dependence on world markets. Both dairies and dairy farmers have therefore started to search for ways to strengthen their competitive positions and to fulfill stakeholders' requirements in order to stay in the market (Friedrich et al., 2012; Heyder and Theuvsen, 2012; Luhmann et al., 2016). Participating in AWPs could create an opportunity for them to take advantage of a more differentiated market segment for milk and milk products produced with higher animal welfare standards which is accepted and financially rewarded by society.

The long-term success of AWPs is determined by a variety of factors, such as consumer behavior and the acceptance of other stakeholders along the food supply chain (Buller and Cesar, 2007; Deimel et al., 2010; Gulbrandsen, 2006). However, farmers are considered the most important stakeholder group for the successful implementation of enhanced FAW standards because they are directly involved in production. Furthermore, most EU dairy farmers are not bound by long-term contracts with downstream production stages. Thus, it is difficult to implement new production or quality programs if the majority of the farmers have doubts about the system with regard to such crucial aspects as its long-term market success (Bahlmann and Spiller, 2008; Franz et al., 2012; Hansson and Lagerkvist, 2012).

Even though many farmers in general consider the topic of FAW as important, previous studies have shown that only a small number of farmers recognize the need for improvement in the level of animal welfare in livestock production systems (Deimel et al., 2010; Franz et al., 2012; Vetouli et al., 2010). Furthermore, most producers look critically at AWPs because of the high economic risk associated with the adjustment of production systems. They also fear that the high investment costs for improved FAW will not pay off due to skepticism regarding market opportunities for animal welfare products and doubts that a sufficient number of consumers are willing to pay more for more animal-friendly products (Franz et al., 2010; Kjærnes et al., 2007; Wolf et al., 2016).

Some studies have already investigated dairy farmers' attitudes toward specific animal welfare-related topics, including mastitis management, participation in disease control programs, and broader quality assurance programs (e.g. Ritter et al., 2015; Schreiner and Latacz-Lohmann, 2015; Valeeva et al., 2007; Wolf et al., 2016). But to our best knowledge, no empirical study has comprehensively investigated dairy farmers' overall attitudes toward FAW and AWPs and their willingness to participate in these programs. This is a considerable 
research gap as Gocsik et al. (2014) showed that positive attitudes among farmers toward AWPs are closely linked to a high willingness to participate in these programs. Furthermore, farmers' attitudes are closely linked to their actual behavior (Breuer et al., 2000; Coleman et al., 1998). Thus, this study analyzes dairy farmers' attitudes toward FAW and AWPs in order to be able to draw conclusions regarding their actual willingness to participate in such programs. As previous studies showed that dairy farmers show very diverse preferences for quality programs that enhance FAW as a side effect (e.g. Luhmann et al., 2016) this study seeks to identify farmer groups with regard to their attitudes toward FAW and AWPs through a factor and subsequent cluster analysis.

Because Germany is the largest milk producer in the EU (Destatis, 2016a) and because FAW is the focus of intense controversy in Germany (Busch, 2016; Kayser and Spiller, 2011;WBA, 2015), we chose to survey German dairy farmers. Due to similar controversies in other parts of the EU, results from Germany can provide important evidence for other countries. We focused on conventional dairy farmers because public criticism mainly concerns intensive production systems, whereas consumers attribute higher animal welfare standards to organic livestock farming (Busch et al., 2013; Harper and Makatouni, 2002; Makatouni, 2002). Furthermore, the products of AWPs could be developed primarily to establish a kind of middle market segment with prices between low-priced conventional and high-priced organic products. Thus, participation in these programs is probably only economically viable for conventional farmers.

This study complements previous research with a comprehensive empirical study aiming to identify different clusters with regard to dairy farmers' attitudes toward FAW and AWPs and their willingness to take part in these programs within the larger group of conventional German dairy farmers. Its results can be considered representative of other dairy markets characterized by similar market conditions regarding FAW standards.

\section{Material and methods}

\subsection{Study design}

Conventional dairy farmers throughout Germany were surveyed in summer 2014 by means of a standardized online survey. Only farmers fully specialized in dairy farming (keeping only dairy cows on their farm) were used in this data set, as the response behavior of farmers from mixed farms (keeping more than one animal species) cannot clearly be assigned to only one type of livestock. The respondents were recruited through various mailing lists and in collaboration with several German agribusiness trade organizations. In this way, we reached the farm owners/managers, as occupational email addresses were used. To avoid that two people from the same farm participated in the survey, the link that led the farmer to the online-survey could be used only once. After deleting incomplete questionnaires and outliers, 258 data sets were left for empirical analysis.

The statements regarding farmers' attitudes toward FAW and AWPs were measured primarily using five-point Likert scales from $-2=$ "I totally disagree" to $+2=$ "I totally agree". Furthermore, nominally scaled questions were used to inquire about sociodemographic and farm characteristics.

The questionnaire was divided into several parts. The first part concentrated on farm characteristics. The next asked participants to indicate what they consider particularly important for the wellbeing of their farm animals. Then, they were asked to evaluate various statements about AWPs and the need to enhance animal welfare standards in conventional livestock production as well as their own willingness to participate in such programs. They were also asked their opinions about the potential market for products from more animalfriendly production. The subsequent part of the questionnaire dealt with farmers' satisfaction with the current situation, the economic and financial position of their farms, and the possible effects of increased national animal welfare requirements on their farms. The final section gathered some sociodemographic characteristics. 


\subsection{Statistical analysis}

The data were evaluated using SPSS (version 24, IBM Corporation, Armonk, NY, USA). First, frequency distributions of farm and sociodemographic characteristics as well as the farmers' perceived financial situation and attitudes toward FAW and AWPs were conducted to acquire a brief overview of the participants. Next, an explorative factor analysis was carried out to reduce the number of items and to capture the central dimensions based on farmers' attitudes toward FAW and AWPs. The analysis contained all Likert-scaled statements concerning farmers' attitudes toward AWPs and FAW, the market effects of higher animal welfare standards, the criteria important for a high level of FAW, and farmers' willingness to improve FAW on their own farms. Variables that correlated highly were grouped together in one factor to separate them from less highly correlated groups. Then, principal component analysis was used to summarize the variables that load highly on one factor. All variables that showed loadings of $\geq 0.4$ on more than one factor were removed from the analysis because they would prevent a clear assignment to only one factor. In order to facilitate the interpretation of the factors, an orthogonal Varimax rotation was used, which permitted us to maximize the variance of the squared factors loadings by column (Backhaus et al., 2011). The quality of the factor analysis was verified using the Kaiser-Meyer-Olkin criterion and the Bartlett test for sphericity with subsequent reliability analysis (Brosius, 2011). In this paper we identified six factors with 20 variables. However, we had to exclude one factor as the reliability analysis showed a Cronbach's Alpha of less than 0.5, indicating that it is not useful to combine these variables in one factor (Bühl, 2011). The final factor solution included five factors with 18 variables. The factor analysis explained $62.55 \%$ of the total variance among the 18 variables. These variables are well-suited for the factor analysis as shown by the Kaiser-Meyer-Olkin measure of sampling adequacy, which is relatively high, at 0.815 . Additionally, Bartlett's test of sphericity was statistically significant, yielding correlation coefficients for the population with values different from zero. A reliability analysis showed that the internal consistency of the factors is adequate (Backhaus et al., 2011; Bühl, 2010).

Based on the extracted factors, cluster analysis was used to classify the farmers into groups according to their attitudes toward FAW and AWPs. The purpose of this analysis was to build homogeneous groups out of a heterogeneous population (Hair et al., 2010), to which end we applied a hierarchical clustering method using an agglomerative algorithm. The cluster analysis was conducted in three steps. First, four outliers were identified and eliminated through the single-linkage method. During this procedure, the objects with the smallest distances between them were combined. Next, we identified five clusters as optimal number using Ward's method. The goal of this procedure was to combine those objects that least increase the variance within a group and through which the most homogeneous clusters are formed. The optimal number of clusters was determined through the heterogeneity measure. Depicting the merger process graphically through a dendrogram and applying the elbow criterion also showed that five clusters led to the best solution (Backhaus et al., 2011). In order to refine the resulting solution, we conducted a K-means cluster analysis with five iterations (Bacher et al., 2010; Backhaus et al., 2011; Janssen and Laatz, 2007) and used a discriminant analysis to check the results of the cluster analysis. Moreover, we used discriminant analysis as a relative validity criterion and confirmed that the accuracy of classification is $98.8 \%$, which meets the requirement stipulated in the literature (Backhaus et al., 2011). Several additional criteria indicate that the solution reached is of high quality. The clusters are very homogeneous as all the F-values are less than 1. Additionally, eta $=0.638$ on average, showing there are significant differences among the cluster-building factors and the variance within the clusters is low. Furthermore, eta ${ }^{2}=0.41$, indicating that, on average, the cluster-building factors can explain $41 \%$ of the variance between the clusters. To characterize the different groups in greater depth and to prove significant differences between the clusters formed, we used post hoc tests, which showed no equity of variance (Brosius, 2011; Everitt, 1998). 


\subsection{Sample description}

The survey respondents are on average 45 years old, and $80.6 \%$ of them are male. These numbers closely match projections of the German Federal Statistical Office (Destatis, 2012). The farmers surveyed have considerable experience, as more than $65 \%$ have been directly involved in farming for more than 20 years. Nearly $55 \%$ of the participants are from Bavaria (36.0\%) and Lower Saxony (18.6\%). This parallels the situation in the entire country as nearly half of all dairy farms are located in these two federal states (Destatis, 2016b). Even though the overall number of dairy cows is currently declining in Germany, the number of dairy cows kept in Lower Saxony and Bavaria has increased over the past year (Destatis, 2016c). Among our participants, $95.3 \%$ work full time on their farms, and, therefore, their farms provide the main source of their income; this contrasts with the German average of only 54\% (Destatis, 2013). In the survey, the average farm size is 201.75 hectares, and participants keep 146 dairy cows and 225 livestock units. Thus, the farms are substantially larger than the German average (Destatis, 2010). However, about $72 \%$ of all dairy cows in Germany live on farms that keep more than 100 dairy cows (Bauernverband, 2016). Due to the convenience sample of our respondents, our dataset is not fully representative of current German dairy farms. However as dairy farms in the near future might undergo substantial changes due to the abolition of the milk quota and the continuing structural changes taking place in the agricultural sector in Germany, results from our sample might give an interesting overview of attitudes towards FAW and AWPs for future orientated dairy farms.

\section{Results}

\subsection{Descriptive results}

The frequencies shown in Table 1 clearly illustrate that farmers' attitudes towards FAW and AWPs are diverse. About $35 \%$ of the surveyed farmers are principally willing to participate in AWPs and more than $50 \%$ agree or rather agree that animal welfare programs are useful for farmers. However, only $27.9 \%$ of them plan to participate in AWPs in the future. Most farmers believe that farmers cannot make more profit by participating in AWPs and only $16.6 \%$ think, that the national animal welfare standards should be enhanced. Nevertheless, more than $65 \%$ of the farmers in this survey would be willing to adapt their barns given reasonable remuneration and about $67 \%$ would like to improve the level of animal welfare on their farms. However, only $33.7 \%$ of the surveyed farmers agree or rather agree that the consumer demand for more animal-friendly products will rise in the upcoming years and nearly $25 \%$ think that participation in AWPs can help to gain competitive advantages. Consequently, the vast majority (79.8\%) of the farmers believe that higher national animal welfare standards will lead to competitive disadvantages and that German livestock production will move abroad if higher national animal welfare standards are required (62.8\%). Furthermore more than $65 \%$ of the farmers expect products from AWPs to remain a niche market only in the years to come. Most farmers are firmly convinced that their livestock production on the farm is animalfriendly $(89.9 \%)$ and many believe that the animals on the farm feel comfortable (95.3\%). More than $77 \%$ of the farmers in this survey think that an animal must be able to show its natural innate behavior and that the structural-technical systems used in the barns are important for the level of animal welfare (85.3\%). When it comes to outdoor access, farmers' response behavior is very mixed: nearly $29 \%$ believe that an animal that never had outdoor access won't miss it while $39.1 \%$ are undecided about this statement and $32.2 \%$ deny it. The figures indicate German dairy farmers' positive basic stance toward the improvement of FAW, even though they are already convinced that their livestock is kept in an animal-friendly way. This response behavior thus might reflect a reaction to the ongoing public debate towards the enhancement of animal welfare standards in livestock production. If this positive attitude can be converted into effective participation in AWPs, there is great potential for the establishment of such programs on the supply side. However, high standard deviations in most of the statements indicated that our group of dairy farmers cannot be understood as one homogeneous group, but that there are subgroups that differ with regard to their attitudes toward FAW and AWPs. To get a more detailed view of the existing subgroups of the farmers and to derive target group specific recommendations, we conducted a cluster analysis. 
Table 1. Descriptive results and results of the factor analysis. ${ }^{1}$

\begin{tabular}{|c|c|c|c|c|}
\hline Factors and statements ${ }^{2}$ & $\mathbf{F L}^{3}$ & $\begin{array}{l}\text { Agreement } \\
\text { in \% }\end{array}$ & $\begin{array}{l}\text { Neutral } \\
\text { in } \%\end{array}$ & $\begin{array}{l}\text { Rejection } \\
\text { in \% }\end{array}$ \\
\hline \multicolumn{5}{|l|}{ Attitudes toward AWPs (Cronbach's Alpha: 0.880) } \\
\hline $\begin{array}{l}\text { In principle, I am willing to participate in animal welfare } \\
\text { programs. }\end{array}$ & 0.838 & 35.7 & 39.5 & 24.8 \\
\hline In principle, animal welfare programs are useful for farmers. & 0.837 & 51.2 & 26.4 & 22.4 \\
\hline I plan to participate in animal welfare programs in the future. & 0.814 & 27.9 & 33.3 & 38.8 \\
\hline $\begin{array}{l}\text { Animal welfare programs can help improve animal welfare for } \\
\text { farm animals. }\end{array}$ & 0.802 & 38.3 & 41.1 & 20.5 \\
\hline $\begin{array}{l}\text { Farmers can make more profit by participating in animal } \\
\text { welfare programs. }\end{array}$ & 0.758 & 22.9 & 36.4 & 40.7 \\
\hline $\begin{array}{l}\text { The national animal welfare standards for conventional } \\
\text { livestock production should be enhanced. }\end{array}$ & 0.489 & 16.6 & 43.4 & 40.0 \\
\hline \multicolumn{5}{|c|}{ Willingness to improve FAW and differentiation through AWPs (Cronbach's Alpha: 0.678) } \\
\hline $\begin{array}{l}\text { Given reasonable remuneration, I would be willing to adapt my } \\
\text { barns to make my livestock more comfortable. }\end{array}$ & 0.766 & 65.9 & 23.3 & 10.8 \\
\hline $\begin{array}{l}\text { I would like to improve the level of animal welfare for the } \\
\text { animals living on my farm. }\end{array}$ & 0.668 & 67.5 & 23.6 & 8.9 \\
\hline $\begin{array}{l}\text { The consumer demand for more animal-friendly products will } \\
\text { rise in coming years. }\end{array}$ & 0.641 & 33.7 & 38.8 & 27.5 \\
\hline $\begin{array}{l}\text { Farmers can gain competitive advantages by participating in } \\
\text { animal welfare programs. }\end{array}$ & 0.560 & 24.8 & 41.9 & 33.4 \\
\hline \multicolumn{5}{|l|}{ Animal welfare and the market (Cronbach's Alpha: 0.601) } \\
\hline $\begin{array}{l}\text { Higher national animal welfare requirements will lead to } \\
\text { competitive disadvantages for German farmers on international } \\
\text { markets. }\end{array}$ & 0.789 & 79.8 & 16.7 & 3.5 \\
\hline $\begin{array}{l}\text { German livestock production will move abroad if higher } \\
\text { national animal welfare standards are required. }\end{array}$ & 0.749 & 62.8 & 28.7 & 8.6 \\
\hline $\begin{array}{l}\text { Products from more animal-friendly production systems will } \\
\text { always occupy market niches only. }\end{array}$ & 0.585 & 65.5 & 24.8 & 9.7 \\
\hline \multicolumn{5}{|l|}{ Perception of own livestock husbandry (Cronbach's Alpha: 0.791) } \\
\hline The animals on my farm are kept in animal-friendly conditions. & 0.886 & 89.9 & 10.1 & 0.0 \\
\hline The livestock on my farm feel comfortable. & 0.850 & 95.3 & 4.7 & 0.0 \\
\hline \multicolumn{5}{|l|}{ Animal behavior and husbandry system (Cronbach's Alpha: 0.556 ) } \\
\hline $\begin{array}{l}\text { An animal must be able to engage in natural behaviors; only } \\
\text { then can it feel comfortable. }\end{array}$ & 0.764 & 77.1 & 18.2 & 4.7 \\
\hline Even an animal that has never had outdoor access can miss it. & 0.720 & 28.7 & 39.1 & 32.2 \\
\hline $\begin{array}{l}\text { The structural-technical systems used in barns are particularly } \\
\text { important for animal welfare. }\end{array}$ & 0.636 & 85.3 & 13.6 & 1.2 \\
\hline
\end{tabular}

\subsection{Results of the factor analysis}

We conducted an explorative factor analysis to reduce complexity and to find the most important factors reflecting dairy farmers' attitudes toward FAW and AWPs (Table 1). The first factor - attitudes toward AWPs - describes the general attitudes of the farmers toward such programs, combining statements concerning 
the usefulness of AWPs, farmers' general willingness to participate in such programs, their future plans to participate in AWPs, and the programs' expected effects on farm profitability. The first factor also includes a statement concerning the need to enhance national animal welfare standards in conventional livestock production. The second factor - willingness to improve FAW and differentiation through AWPs - combines three statements concerning farmers' willingness to adapt their barns and improve the level of animal welfare on their farms and the development of consumer demand for more animal-friendly products in coming years. The fourth statement in this factor deals with how farmers perceive their ability to gain competitive advantages by participating in AWPs. The third factor - animal welfare and the market - comprises variables that reflect the farmers' positions toward the market effects of higher animal welfare standards and the products of more animal-friendly husbandry systems. This factor also includes a statement addressing farmers' perception of the future market development for products from more animal-friendly production systems. The fourth factor - perception of one's own animal husbandry - summarizes two statements about how farmers perceive how livestock is kept on their own farms. The last factor - animal behavior and husbandry system - combines three statements about the relative importance to the level of FAW of animals' opportunity to engage in natural innate behaviors, animals' outdoor access, and the structural and technical equipment of barns.

Next, the factors we identified were used as cluster-building variables to define target groups for participation in AWPs.

\subsection{Results of the cluster analysis}

The goal of the cluster analysis was to assign the farmers to clusters according to their attitudes toward FAW and AWPs and to derive different target groups for participation in an AWP. Table 2 gives the results of the cluster analysis, showing the means of the cluster-building factors.

The first cluster is characterized by strong opposition to AWPs and higher animal welfare standards in German livestock husbandry. We called this group of farmers "convinced animal welfare opponents (the opponents)." With only 45 participants, this is the smallest cluster. These farmers disagree with all statements concerning AWPs, the ability to make more profit through AWPs, and the enhancement of national animal welfare standards $(\mu=-0.52 ; \mathrm{SD}=0.86$ ). They are comparatively unwilling to improve their level of FAW, and they do not believe the consumer demand for more animal-friendly products will rise. They also reject the possibility of gaining competitive advantages through participation in AWPs $(\mu=-0.92$; $\mathrm{SD}=0.90)$. Furthermore, they are very skeptical about the market for more animal-friendly products and anticipate disadvantages from

Table 2. Results of the cluster analysis. ${ }^{1}$

\begin{tabular}{|c|c|c|c|c|c|c|}
\hline Cluster-building factors $^{2}$ & $\begin{array}{l}\text { The } \\
\text { opponents }\end{array}$ & $\begin{array}{l}\text { The } \\
\text { skeptics }\end{array}$ & $\begin{array}{l}\text { The } \\
\text { unconcerned }\end{array}$ & $\begin{array}{l}\text { The } \\
\text { improvers }\end{array}$ & $\begin{array}{l}\text { The } \\
\text { friends }\end{array}$ & F-values \\
\hline Sample size (n/\%) & $45 / 17.44$ & $53 / 20.54$ & $48 / 18.60$ & $58 / 22.48$ & $54 / 20.93$ & \\
\hline Attitudes toward AWPs ${ }^{* * *}$ & $-0.52^{\mathrm{a}}$ & $-0.62^{\mathrm{a}}$ & $-0.29^{\mathrm{a}}$ & $0.58^{\mathrm{b}}$ & $0.66^{\mathrm{b}}$ & 29.53 \\
\hline $\begin{array}{l}\text { Willingness to improve FAW and } \\
\text { differentiation through AWPs }{ }^{* * *}\end{array}$ & $-0.93^{\mathrm{a}}$ & $-0.16^{\mathrm{b}}$ & $0.17^{\mathrm{b}}$ & $0.64^{\mathrm{c}}$ & $0.26^{\mathrm{b}}$ & 26.02 \\
\hline Animal welfare and the market ${ }^{* * *}$ & $0.41^{\mathrm{a}}$ & $0.31^{\mathrm{a}}$ & $-0.99^{b}$ & $0.88^{\mathrm{c}}$ & $-0.64^{b}$ & 66.93 \\
\hline $\begin{array}{l}\text { Perception of own livestock } \\
\text { husbandry }{ }^{* * *}\end{array}$ & $0.28^{\mathrm{a}}$ & $-0.59^{b}$ & $0.91^{\mathrm{c}}$ & $0.53^{\mathrm{a}}$ & $-0.99^{d}$ & 70.89 \\
\hline $\begin{array}{l}\text { Animal behavior and husbandry } \\
\text { system.** }\end{array}$ & $-1.02^{\mathrm{a}}$ & $0.96^{\mathrm{b}}$ & $0.16^{\mathrm{c}}$ & $0.03^{\mathrm{cd}}$ & $-0.33^{d}$ & 44.45 \\
\hline
\end{tabular}

${ }^{1}$ Significance level at ${ }^{*} P \leq 0.05 ;{ }^{* *} P \leq 0.01 ;{ }^{* * *} P \leq 0.001 ;{ }^{\text {ns }} P \geq 0.05$ (not significant); ${ }^{\text {a } b \mathrm{c} \mathrm{d} \text { e }}$ mean values with no common letter are significantly different (Tamhane's T2 post-hoc test); AWPs = animal welfare programs; FAW = farm animal welfare.

2 The factor means are weighted scores based on the factor loadings shown in Table 1. For detailed information about the factorbuilding variables see Supplementary Table S1; $\mathrm{n}=258$. 
higher national animal welfare standards $(\mu=0.41 ; \mathrm{SD}=0.65)$. Farmers in this cluster perceive their own livestock husbandry as good $(\mu=0.28 ; \mathrm{SD}=0.65)$ and attach comparatively little importance to providing opportunities for animals to engage in natural innate behaviors and to using structural-technical systems in barns that increase the level of animal welfare $(\mu=-1.02 ; \mathrm{SD}=0.72)$.

The second cluster consists of "moderate animal welfare skeptics (the skeptics)". 53 farmers are placed in this cluster. They have fairly negative attitudes toward AWPs and higher animal welfare standards in livestock husbandry $(\mu=-0.62 ; \mathrm{SD}=0.88)$. However, they are somewhat willing to improve the level of animal welfare on their farm despite the fact that they do not think that there is rising consumer demand or that they could gain competitive advantages from participating in AWPs $(\mu=-0.16 ; \mathrm{SD}=0.88)$. They rate their own livestock husbandry rather positively $(-\mu=0.59 ; \mathrm{SD}=0.78)$ but are not as convinced as most of the other clusters. These farmers are also skeptical about the market effects of enhanced animal welfare standards $(\mu=0.31 ; \mathrm{SD}=0.69)$. Nevertheless, they attach more importance than others to providing opportunities for animals to engage in natural innate behaviors and to improving the structural-technical systems in barns and believe that these factors strongly influence the level of FAW $(\mu=0.96 ; \mathrm{SD}=0.69)$.

We describe the third cluster as the "optimistic unconcerned (the unconcerned)". 48 farmers are placed in this cluster. They rate all statements of factor $1(\mu=-0.29 ; \mathrm{SD}=0.83)$ around zero. On average, therefore, the farmers in this cluster have neither a negative nor a positive attitude toward AWPs. They are slightly willing to improve animal welfare on their own farms but are somewhat undecided concerning the future development of consumer demand and the likelihood of gaining competitive advantages through participation in AWPs $(\mu=0.17 ; \mathrm{SD}=0.88)$. The farmers in this cluster are the most optimistic about the potential market effects of higher animal welfare standards in Germany $(\mu=-0.99 ; \mathrm{SD}=0.66)$ and are most convinced of their own livestock husbandry $(\mu=0.91 ; \mathrm{SD}=0.50)$. The opportunity for animals to engage in natural innate behaviors and the use of animal-friendly structural-technical systems in barns are somewhat important for the members of cluster $\mathrm{C}(\mu=0.16 ; \mathrm{SD}=0.80)$.

Cluster four comprises the "market-conscious animal welfare improvers (the improvers)." With 58 groupmembers, this cluster is the largest. They have a positive attitude toward AWPs in general but are also undecided about the monetary effects of participation in AWPs and higher animal welfare standards $(\mu=0.57$; $\mathrm{SD}=0.86$ ). They are also willing to improve animal welfare on their own farms, but again are not convinced that consumer demand for products from more animal-friendly production systems is rising or that they can gain competitive advantages from participating in AWPs $(\mu=0.64 ; \mathrm{SD}=0.74)$. This cluster is most skeptical about the market effects of higher animal welfare standards $(\mu=0.88 ; \mathrm{SD}=0.57)$ and comparatively convinced of their own livestock husbandry $(\mu=0.53 ; \mathrm{SD}=0.76)$. Furthermore, members of cluster $\mathrm{D}$ ascribe the least importance to animals engaging in innate behaviors and structural-technical husbandry systems for animal welfare $(\mu=0.03 ; \mathrm{SD}=0.78)$.

The last cluster consists of the "self-critical animal welfare friends (the friends)". The 54 farmers in this cluster have the most positive attitude toward AWPs $(\mu=0.66 ; \mathrm{SD}=0.65)$. They are willing to improve the level of animal welfare on their farms and are slightly optimistic about the development of consumer demand for more animal-friendly products and the opportunity to gain competitive advantages through participation in AWPs $(\mu=0.26 ; \mathrm{SD}=0.70)$. However, these farmers slightly agree that higher animal welfare standards will cause problems for German farmers and that products from more animal-friendly production systems will occupy only market niches $(-0.64 ; \mathrm{SD}=0.82)$. Still, they are not as critical as most of the other clusters. Farmers of this cluster are the most critical of their own livestock keeping ( $\mu=-0.99 ; \mathrm{SD}=0.64)$. They rate animals' opportunity to engage in natural innate behaviors and the structural-technical equipment of the barns as somewhat important for the level of animal welfare; compared to most of other clusters, this is rather low.

The clusters differ in some interesting sociodemographic and farm characteristics, which we show in Table 3. However, most of these differences are not at significant levels. 
Table 3. Sociodemographic and farm characteristics of the clusters. ${ }^{1}$

\begin{tabular}{|c|c|c|c|c|c|}
\hline & $\begin{array}{l}\text { The } \\
\text { opponents }\end{array}$ & $\begin{array}{l}\text { The } \\
\text { skeptics }\end{array}$ & $\begin{array}{l}\text { The } \\
\text { unconcerned }\end{array}$ & $\begin{array}{l}\text { The } \\
\text { improvers }\end{array}$ & $\begin{array}{l}\text { The } \\
\text { friends }\end{array}$ \\
\hline Sample size (n/\%) & $45 / 17.44$ & $53 / 20.54$ & $48 / 18.60$ & $58 / 22.48$ & $54 / 20.93$ \\
\hline$\varnothing$ Age (in years) ${ }^{\text {ns }}$ & 46.40 & 47.25 & 45.15 & 42.21 & 45.72 \\
\hline $20-30$ years $(\%)^{n s}$ & 15.6 & 3.8 & 12.5 & 12.1 & 20.4 \\
\hline $31-40$ years $(\%)^{* *}$ & $6.7^{\mathrm{b}}$ & $20.8^{\mathrm{a}}$ & $18.8^{\mathrm{ab}}$ & $31.0^{\mathrm{a}}$ & $8.9^{\mathrm{b}}$ \\
\hline $41-50$ years $(\%)^{n s}$ & 35.6 & 32.1 & 29.2 & 43.1 & 31.5 \\
\hline $51-60$ years $(\%)^{* *}$ & $33.3^{\mathrm{a}}$ & $41.5^{\mathrm{a}}$ & $35.4^{\mathrm{a}}$ & $10.3^{\mathrm{b}}$ & $33.3^{\mathrm{a}}$ \\
\hline$\geq 60$ years $(\%)^{n s}$ & 8.9 & 1.9 & 4.2 & 3.4 & 7.4 \\
\hline Share of women (\%) ${ }^{\text {ns }}$ & 20.0 & 9.4 & 16.7 & 24.1 & 25.9 \\
\hline$\varnothing$ Farm size (in hectares) ${ }^{\mathrm{ns}}$ & 181.58 & 188.72 & 166.60 & 246.73 & 214.26 \\
\hline$\leq 20$ ha $(\%)^{\mathrm{ns}}$ & 4.4 & 3.8 & 4.2 & 0.0 & 5.6 \\
\hline $21-50$ ha $(\%)^{*}$ & $13.3^{\mathrm{a}}$ & $24.5^{\mathrm{a}}$ & $12.5^{\mathrm{a}}$ & $1.7^{b}$ & $13.0^{\mathrm{a}}$ \\
\hline $51-100$ ha $(\%)^{*}$ & $48.9^{\mathrm{a}}$ & $17.0^{\mathrm{b}}$ & $31.3^{\mathrm{bc}}$ & $31.0^{\mathrm{bc}}$ & $35.2^{\mathrm{ac}}$ \\
\hline $101-200$ ha $(\%)^{\text {ns }}$ & 24.4 & 43.3 & 35.4 & 50.0 & 31.5 \\
\hline$\geq 201$ ha $(\%)^{\mathrm{ns}}$ & 8.9 & 11.3 & 16.7 & 17.2 & 14.8 \\
\hline$\varnothing$ number of animals kept (in livestock units) ${ }^{\text {ns }}$ & 215 & 210 & 203 & 251 & 239 \\
\hline$\varnothing$ number of dairy cows kept ${ }^{\text {ns }}$ & 148 & 130 & 124 & 162 & 162 \\
\hline
\end{tabular}

We found some significant differences with regard to the age composition of the clusters. "The opponents" and "the friends" have less participants in the age between 31 to 40 years compared to "the skeptics", "the unconcerned" and "the improvers" also the cluster with the lowest number of participants between 51 and 60. "The improvers" and "the friends" contain more women, - although again, the differences were not significant. These two clusters also operate the largest farms. The farmers in both clusters cultivate on average more than 200 hectares and keep the most animals; again, however, the differences are not at a significant level. What is significant, though, is that fewer members of "the improvers" have farms between 21 and 50 hectares. Furthermore, members of the "convinced animal welfare opponents," most often work on farms with 51 to 100 hectares, while farmers in "the skeptics" less frequently cultivate farms in this size.

In order to investigate the possible effects of enhanced animal welfare standards for the financial situation of the farmers, Table 4 shows respondents' perceived economic farm situation and perceived effects of higher animal welfare standards. Overall, the farmers are rather satisfied with their general economic situation $(\mu=0.79 ; \mathrm{SD}=0.84)$ since they are able to generate equity $(\mu=0.54 ; \mathrm{SD}=1.19)$ and somewhat agree that their long-term solvency is secure $(\mu=0.84 ; \mathrm{SD}=0.97)$. However, they vary greatly in how they rate the opportunity to gain satisfactory profits from their farms $(\mu=0.42 ; \mathrm{SD}=1.14)$. When it comes to the effects of enhanced animal welfare standards, their opinions are also diverse $(\mu=0.05 ; \mathrm{SD}=1.09)$. More than $30 \%$ agree or somewhat agree that additional national animal welfare requirements could threaten the existence of their farms; conversely, nearly $30 \%$ do not agree that additional animal welfare requirements could threaten the existence of their farms.

Comparing the five clusters clearly shows that the perception of their farm's financial situation and the effects of enhanced animal welfare standards differ significantly among the clusters. The economic situation of "the opponents", "the sceptics" and "the friends" is similar. These groups are moderately satisfied with their overall situation but are undecided as to whether the farm profits are satisfactory. Nevertheless, these farmers rather agree that they always meet payment obligations on time and that their farms will remain solvent in the long run. Members of the "convinced animal welfare opponents" are slightly optimistic about their ability to generate equity from the farm but are rather convinced that higher national animal welfare 
Table 4. Famers' satisfaction with the farm situation. ${ }^{1}$

\begin{tabular}{|c|c|c|c|c|c|c|}
\hline The opponents & $\begin{array}{l}\text { The } \\
\text { opponents }\end{array}$ & $\begin{array}{l}\text { The } \\
\text { skeptics }\end{array}$ & $\begin{array}{l}\text { The } \\
\text { unconcerned }\end{array}$ & $\begin{array}{l}\text { The } \\
\text { improvers }\end{array}$ & $\begin{array}{l}\text { The } \\
\text { friends }\end{array}$ & F-values \\
\hline Sample size $(\mathrm{n} / \%)^{2}$ & $45 / 17.44$ & $53 / 20.54$ & $48 / 18.60$ & $58 / 22.48$ & $54 / 20.93$ & \\
\hline $\begin{array}{l}\text { I am satisfied with the general } \\
\text { economic situation of my farm. }\end{array}$ & $0.91^{\mathrm{ac}}$ & $0.49^{\mathrm{ab}}$ & $1.04^{\mathrm{c}}$ & $1.09^{\mathrm{c}}$ & $0.40^{\mathrm{ab}}$ & 7.60 \\
\hline $\begin{array}{l}\text { I can gain satisfactory profit from my } \\
\text { farm. }\end{array}$ & $0.27^{\mathrm{a}}$ & $0.11^{\mathrm{a}}$ & $0.52^{\mathrm{ab}}$ & $0.95^{\mathrm{b}}$ & $0.19^{\mathrm{a}}$ & 5.33 \\
\hline $\begin{array}{l}\text { I can always meet my payment } \\
\text { obligations on time. }\end{array}$ & $1.13^{\mathrm{ab}}$ & $0.66^{\mathrm{a}}$ & $1.23^{\mathrm{ab}}$ & $1.33^{b}$ & $1.11^{\mathrm{ab}}$ & 4.02 \\
\hline $\begin{array}{l}\text { The long-term solvency of my farm is } \\
\text { secure. }\end{array}$ & $0.73^{\mathrm{ab}}$ & $0.57^{\mathrm{a}}$ & $1.10^{\mathrm{b}}$ & $1.09^{b}$ & $0.72^{\mathrm{ab}}$ & 3.30 \\
\hline $\begin{array}{l}\text { My farm is running so well that I am } \\
\text { able to generate equity. }\end{array}$ & $0.51^{\mathrm{ab}}$ & $0.21^{\mathrm{a}}$ & $0.65^{\mathrm{ab}}$ & $1.12^{b}$ & $0.19^{\mathrm{a}}$ & 6.26 \\
\hline $\begin{array}{l}\text { Enhanced national animal welfare } \\
\text { requirements might place my farm in an } \\
\text { economic situation that could threaten } \\
\text { its existence. }\end{array}$ & $0.56^{\mathrm{a}}$ & $0.30^{\mathrm{ac}}$ & $-0.33^{b d}$ & $0.02^{\mathrm{ad}}$ & $-0.26^{\mathrm{cd}}$ & 6.17 \\
\hline
\end{tabular}

standards will put their farm in an economic situation that threatens their existence. Farmers of the "moderate animal welfare skeptics," and the "self-critical animal welfare friends," are not convinced they can gain equity from farming and are undecided about the effects of higher national animal welfare standards for their farms.

The financial situations of the "optimistic unconcerned," and the "market-conscious animal welfare improvers," are also comparable. These two groups are the most satisfied with their economic situation. They can meet their payment obligations on time, enjoy secure long-term solvency, and can generate equity from farming. Farmers in the cluster "the unconcerned" are the most optimistic about the financial effects of higher animal welfare standards for their farms, but still, farmers in both cluster C and cluster D rate this statement only in the zero range.

\section{Discussion and conclusions}

This study analyzed the results of an online survey of 258 dairy farmers from all over Germany concerning their attitudes toward FAW and AWPs as well as factors important for FAW. The descriptive results showed that in general dairy farmers rated statements concerning AWPs quite diversely but were on the whole willing to improve animal welfare on their farms and consider the structural-technical husbandry system and animals' opportunity to engage in natural innate behaviors as important for animal welfare. The market potential for products from more animal-friendly production systems and the effects of higher animal welfare standards were viewed with some skepticism. However, high standard deviations indicated that our group of dairy farmers could not be understood as one homogeneous group; there were subgroups that differed with regard to their attitudes toward FAW and AWPs. These results were in line with the findings of Jahn et al. (2005) and Luhmann et al. (2016), who also determined that there are different target groups among farmers regarding participation in certification schemes.

We were able to identify five clusters (farmer groups); based on these clusters, we determined target groups for participation in AWPs. The clusters that were comparatively critical towards AWPs and FAW (clusters A and B) differed only slightly and, thus, showed different nuances concerning their attitudes towards FAW and 
AWPs. So did the clusters that were more optimistic towards AWPs and FAW (clusters D and E). However, between the comparatively critical clusters and the more optimistic ones, there were strong differences regarding attitudes and willingness to participate in AWPs.

Our results confirmed the findings of Coleman et al. (1998), Breuer et al. (2000) and Gocsik et al. (2015), who showed a positive relationship between attitude toward FAW and higher willingness to participate in quality programs or AWPs.

To transfer farmers' attitudes into corresponding behavior, it is necessary to establish particularly well adapted concepts. However, previous studies showed that monetary incentives constitute one of the most important motives for participation in a quality program or a specialized AWP (Franz et al., 2012; Hubbard, 2012; Swinton et al., 2015). Our study clearly indicates that, so far, dairy farmers remained largely unconvinced that participation in an AWP will provide an opportunity to gain additional profit. Furthermore, the market for products from particularly animal-friendly production was viewed rather skeptically by most dairy farmers. Even the "moderate animal welfare skeptics" and the "market-conscious animal welfare improvers," who had, in principle, a high willingness to improve FAW, tended to evaluate the market for animal welfare products rather pessimistically. These results showed that farmers' willingness to participate in AWPs is not just a question of attitude. The decision is strongly influenced by monetary factors closely linked to the market in which the farmers operate. Moreover, previous studies showed that for some farmers internal nonmonetary factors, such as taking pleasure in healthy animals, producing high quality products and working under improved working conditions were indeed strong motivators (Huijps et al., 2010; Kjærnes et al., 2007; Leach et al., 2010; Valeeva et al., 2007; Vetouli et al., 2012). The opportunity to escape from the pressure of ongoing farm growth by earning more per animal and the chance to stabilize trade relations with processors were also cited as motivations for participation in AWPs (Kjærnes et al., 2007).

The named studies showed that farmers' production decision is multidimensional and complex. Thus it is necessary to secure both, monetary and non-monetary benefits for farmers when designing AWPs to convince them from participation in such programs.

However, preferences and attitudes are said to be relatively stable and durable cognitive orientations (Weber et al., 2005). Therefore, it is highly likely that there are mobility barriers between the individual clusters so that farmers will probably remain in one group for the long term. In this sense, the empirical findings were in accordance with more recent research on path dependencies, which proposed that cognitive lock-ins can inhibit firms from changing a once successful but now outdated business model (Ackermann, 2001; Miller, 1993).

Even though many EU consumers advocate higher animal welfare standards (Burda Community Network, 2009; EC, 2007; Lusk and Norwood, 2012), they currently still face a number of key barriers when trying to purchase more animal-friendly products: lack of appropriate information on animal welfare standards, information overload and asymmetries, lack of availability of more animal-friendly products in retail shops, perceived lack of individual influence on overall welfare standards in livestock production, disassociation from food production and high additional costs (Harper and Henson, 2001). The named barriers often result in considerable attitude-behavior discrepancies, also known as the "consumer-citizen gap" (Coff et al., 2008; Harvey and Hubbard, 2013; Vanhonacker et al., 2010). This gap might be a reason why many dairy farmers rated the development of the animal welfare segment rather pessimistically since they are not convinced that the consumer demand will rise in coming years. To transfer consumers' indicated willingness-to-pay into corresponding behavior, it is particularly important to reduce the named barriers. Furthermore, previous studies showed that consumers had different attitudes towards FAW as well as diverse sociodemographic characteristics and shopping habits (De Jonge et al., 2015 Vanhonacker et al., 2007). AWPs that are differentiated in terms of animal welfare levels and require price premiums could, therefore, address both consumers' and farmers' diverse concerns and expectations. Thus, there is high potential for a for a broad market segment of dairy products with appropriate market segmentation which enables consumers to make product choices according 
to their individual preferences (De Jonge and Van Trijp, 2013) and farmers to produces according to their attitudes and farm situation.

Most non-experimental research studies have to deal with some limitations, and so has ours. Firstly, the study was not fully representative for current dairy farms in Germany, as the sample composition differs compared to the basic population of German dairy farmers (e.g. Destatis 2010 and 2013). Our sample consisted of large farms averaging more than 100 dairy cows and thus probably represented typical dairy farms of the near future, as the abolition of the milk quota and ongoing structural changes in the market will lead to larger and more highly specialized farms. As farmers of larger farms in this sample showed a higher willingness to participate in AWPs, a certain overestimation of the real willingness to participate in AWPs among German dairy farmers cannot fully be excluded. Secondly, there might be some selection bias because farmers interested in FAW are probably overrepresented in our sample as they would be most motivated to participate in the survey. However, this bias could be targeted in both directions: Farmers who were positively interested might have participated to advance scientific results from the topic of FAW and AWPs and farmers who were negatively interested might have filled out the questionnaire to express their concerns with regard to further enhanced regulations on FAW. Thirdly, social desirability bias may have led some farmers to indicate a more positive attitude and willingness to participate in AWPs than they actually have. Furthermore, all statements in the questionnaire were framed positively. This design might have provoked the participating farmers towards agreement. These factors could lead to an overestimation of farmers' positive attitudes toward and willingness to participate in AWPs. Another point that needs to be mentioned is that our data is from 2014. Due to the abolition of the milk quota in 2015, many dairy farms in Germany currently find their existence threatened, and farmers would probably rate their economic situation worse now than in 2014. Participation in AWPs might therefore have become a production alternative even for dairy farmers who had not planned to take part in these programs.

Furthermore, dairy farmers' indicated willingness to join an AWP should not be interpreted as actual behavior. To establish a broader market segment of animal welfare products, it is important to transfer farmers' positive attitudes and indicated willingness to participate in AWPs into corresponding behavior. However, the theory of planned behavior (Ajzen, 1991) and similar decision theories clearly showed that a positive attitude can be considered a foundation for a decision to participate. To reduce discrepancies between farmers' attitudes and their actual behavior, existing barriers to participation in AWPs need to be decreased. These barriers include the financial (un-)attractiveness of AWPs, the reservations of other stakeholders along the food supply chain (Buller and Cesar, 2007), and the often difficult practicability of important animal welfare measures (Heise and Theuvsen, 2017). In this study we only investigated farmers' attitudes and their willingness to participate in animal welfare programs without specifying these programs in detail. This might also have influenced the response behavior of the farmers, as the practicability of the required additional animal welfare measures remained unclear.

\section{Conclusions and implications}

Our study shows interesting results for various stakeholders in the agricultural and food sectors. Furthermore, it can contribute to the development of AWPs in the dairy sector that meet the needs of certain target groups.

To acquire an even broader consensus concerning AWPs among dairy farmers, it is important to convince more stakeholders along the food supply chain of the usefulness of AWPs. It is also essential to create further financial incentives to encourage even larger numbers of dairy farmers to take part in these programs. Moreover, dairy farmers should have the opportunity to choose between several AWPs requiring differing levels of animal welfare standards to produce in accordance with their individual attitudes and on-farm situation.

Some political implications can also be drawn from our study. Currently, dairy farmers fear that higher national standards will lead to competitive disadvantages and threaten the existence of their farms. Politicians should consider this concern when deciding on new legal animal welfare requirements. New national legislation is 
obviously not useful for inspiring dairy farmers to adopt a higher level of FAW. Voluntary animal welfare labels or industry solutions that are financially supported by the government through such means as second pillar payments under the Common Agricultural Policy of the EU could result in a higher willingness among dairy farmers to support this development. This would make it possible to meet the requirements of considerable segments of society and create new distribution channels for conventional dairy farmers.

Future research could investigate in greater depth the financial effects of participating in animal welfare related programs (e.g. sustainability programs, pasture raised milk programs or broader quality programs) on the economic success of a farm. At the moment, many farmers fear that participation does not pay off. But so far, no scientific study has examined whether this assumption is true. The financial effects could be analyzed through propensity score matching, which allows researchers to control for differences between participants and nonparticipants in AWPs (regarding such factors as farm size or other personal and farm characteristics) and thus makes participants statistically comparable to other conventional farmers who do not participate in any animal welfare-related programs. Furthermore, future research should try to find practicable solutions for the implementation of many animal welfare measures to simplify the enhancement of the animal welfare level on farm.

\section{Acknowledgements}

This study is part of the project Animal Welfare in Intensive Livestock Production Systems. Financial support from the Lower Saxony Ministry of Science and Culture is gratefully acknowledged.

\section{Supplementary material}

Supplementary material can be found online at https://doi.org/10.22434/IFAMR2017.0066.

Table S1. Results of the cluster analysis.

\section{References}

Ackermann, R. 2001. Pfadabhängigkeit, Institutionen und Regelreform. Mohr Siebeck, Tübingen, Germany. Ajzen, I. 1991. The theory of planned behavior. Organizational Behavior and Human Decision Processes 90 (2): 179-211

Bacher, J., A. Pöge and K. Wenzig. 2010. Clusteranalyse. Anwendungsorientierte Einführung in Klassifikationsverfahren. Vol. 3. Oldenbourg Wissenschaftsverlag, Munich, Germany.

Backhaus, K., E. Erichson, W. Plinke and R. Weiber. 2011. Multivariate Analysemethoden: Eine anwenderorientierte Einführung. Springer, Berlin/Heidelberg, Germany.

Bahlmann, J. and A. Spiller. 2008. Wer koordiniert die Wertschöpfungskette? Fleischwirtschaft 8(88): 23-29.

Bauernverband. 2016. Betriebe und Betriebsgrößen. Available at: http://tinyurl.com/ydckv2do.

Bock, B.B. and M.M. van Huik. 2007. Animal welfare: the attitudes and behavior of European farmers. British Food Journal 109 (11): 931-944.

Boogard, B.K., B.B. Bock, S.J. Oosting, J.S.C. Wiskerke and A.J. van der Zijpp. 2010. Social acceptance of dairy farming: the ambivalence between two faces of modernity. Journal of Agricultural and Environmental Ethics 24(3): 259-282.

Bracke, M.B.M. 2007. Animal-based parameters are no panacea for on-farm monitoring of animal welfare. Animal Welfare 16(2): 229-231.

Breuer, K., P.H. Hemsworth, J.L. Barnett, L.R. Metthews and G.J. Coleman. 2000. Behavioural response to humans and the productivity of commercial dairy cows. Applied Animal Behaviour Science 66: 273-288.

Brosius, F. 2011. SPSS 19. Mitp, Heidelberg/Munich, Germany.

Bühl, A. 2010. SPSS 18 Einführung in die moderne Datenanalyse. Pearson, Munich, Germany.

Bühl, A. 2011. SPSS 20 Einführung in die moderne Datenanalyse. Pearson, Munich, Germany. 
Buller, H. and C. Cesar. 2007. Eating well, eating fare: farm animal welfare in France. International Journal of Sociology of Agriculture and Food 15(3): 45-58.

Burda Community Network. 2009. Typologie der Wünsche 2009: Menschen-Medien-Märkte. Burda Community Network, Offenburg, Germany.

Busch, G. 2016. Nutztierhaltung und Gesellschaft. Kommunikationsmanagement zwischen Landwirtschaft und Öffentlichkeit. PhD thesis, University of Goettingen, Germany.

Busch, G., M. Kayser and A. Spiller. 2013. Factory farming from a consumer's perspective: Associations and attitudes. Jahrbuch der Österreichischen Gesellschaft für Agrarökonomie 22(1): 61-70.

Busse, T. 2015. Die Wegwerfkuh: Wie unsere Landwirtschaft Tiere verheizt, Bauern ruiniert, Ressourcen verschwendet und was wir dagegen tun können. Karl Blessing Publishing, Munich, Germany.

Coff, C., M. Korthals and D. Barling. 2008. Ethical traceability and informed food choice. ethical traceability and communicating food. In: International library of environmental, agricultural and food ethics Vol. 15, edited by C. Coff, D. Barling, M. Korthals and N. Thorkild. Springer, Dordrecht, the Netherlands, pp. 1-18.

Coleman, G.J., P.H. Hemsworth and M. Hay. 1998. Predicting stockperson behavior towards pigs from attitudinal and job-related variables and empathy. Applied Animal Behaviour Science 58: 63-75.

De Jonge, J. and H.C.M. van Trijp. 2013. Meeting heterogeneity in consumer demand for animal welfare: a reflection of existing knowledge and implication for the meat sector. Journal of Agricultural and Environmental Ethics 26: 629-661.

De Jonge, J., I.A. van der Lans and H.C.M. van Trijp. 2015. Different shades of grey: Compromise products to encourage animal friendly consumption. Food Quality Preference 45: 87-99.

Deimel, I., A. Franz, M. Frentrup, M. von Meyer, A. Spiller and L. Theuvsen. 2010. Perspektiven für ein Europäisches Tierschutzlabel. Available at: http://download.ble.de/08HS010.pdf.

Deimel, I., Franz, A. and A. Spiller. 2011. Das „Animal Welfare“-Verständnis deutscher Schweinemäster: Eine Analyse landwirtschaftlicher Frames. Jahrbuch der Österreichischen Gesellschaft für Agrarökonomie 20(2): 191-200.

Destatis. 2010. Landwirtschaftszählung 2010. Landwirtschaftliche Betriebe und landwirtschaftlich genutzte Fläche nach Größenklassen der landwirtschaftlich genutzten Fläche 2010. Available at: http://tinyurl. com/y92bjnlu.

Destatis. 2012. Nur 8\% der landwirtschaftlichen Betriebe werden von Frauen geführt. Available at: http:// tinyurl.com/y8b55r9z.

Destatis. 2013. Land- und Forstwirtschaft, Fischerei. Sozialökonomische Verhältnisse Agrarstrukturerhebung. Available at: http://tinyurl.com/y815sf9t.

Destatis. 2016a. Deutschland größter Milcherzeuger in der EU. Available at: http://tinyurl.com/yb6yjegg.

Destatis. 2016b. Tiere und tierische Erzeugung. Landwirtschaftlcihe Betriebe mit Haltung von Rindern am 1. März 2013 nach Bestandsgrößenklassen und Bundesländern. Available at: http://tinyurl.com/y7es36k5.

Destatis. 2016c. Trotz sehr niedriger Milchpreise nur leichter Rückgang bei den Milchkühen. Available at: http://tinyurl.com/yawy37zc.

European Commission (EC). 2006. A community action plan on the protection and welfare of animals 20062010. Official Journal of the European Union C: 49.

European Commission (EC). 2007. Attitudes of consumers towards the welfare of farmed animals. Special Eurobarometer. Available at: http://tinyurl.com/yal2mlfo.

Everitt, B.S. 1998. The Cambridge dictionary of statistics. Cambridge University Press, Cambridge, UK.

Franz, A., I. Deimel and A. Spiller. 2012. Concerns about animal welfare: a cluster analysis of German pig farmers. British Food Journal 114(10): 1445-1462.

Friedrich, N., M. Heyder and L. Theuvsen. 2012. Sustainability management in agribusiness: challenges, concepts, responsibilities and performance. International Journal on Food System Dynamics 3(2): 123-135.

Gocsik, É., H.W. Saatkamp, C.C. De Lauwere and A.G.J.M. Lansink. 2014. A conceptual approach for a quantitative economic analysis of farmers' decision-making regarding animal welfare. Journal of Agricultural and Environmental Ethics 27(2): 287-308. 
Gocsik, É., I.A. van der Lans, A.G.J.M. Lansink and H.W. Saatkamp. 2015. Willingness of Dutch broiler and pig farmers to convert to production systems with improved welfare. Animal Welfare 24 (2): 211-222.

Gulbrandsen, L.H. 2006. Creating markets for eco-labelling: are consumers insignificant? International Journal of Consumer Studies 30(5): 477-489.

Hair, J., F. Black, B.J. Babin and R.E. Anderson. 2010 Multivariate data analysis: a global perspective. Pearson, Upper Saddle River, NJ, USA.

Hansson, H. and C.J. Lagerkvist. 2012. Measuring farmers`attitudes to animal welfare and health. British Food Journal 114(6): 840-852.

Harper, G. and S. Henson. 2001. Consumer concerns about animal welfare and the impact on food choice. EU-Project EU-FAIR-CT-98-3678. Final Report. Centre for Food Economics Research, Department of Agriculture and Food Economics. The University of Reading, Reading, UK.

Harper, G. and A. Makatouni. 2002. Consumer perception of organic food production and farm animal welfare. British Food Journal 104 (3/4/5): 287-299.

Harvey, D. and C. Hubbard. 2013 Reconsidering the economy of farm animal welfare: an anatomy of market failure. Food Policy 38:105-114.

Heerwagen, L.R., T. Christensen and P. Sandoe. 2013. The prospect of market-driven improvements in animal welfare: lessons from the case of grass milk in Denmark. Animals 3: 499-512.

Heise, H. and L. Theuvsen. 2017. Welche Tierwohlmaßnahmen sollten in einem Tierwohlprogramm umgesetzt werden? German Journal of Agricultural Economics 66 (4): 265-280

Hellberg-Bahr, A., N. Steffen and A. Spiller. 2012. Marketingpotentiale für Weidemilch. Jahrbuch der Österreichischen Gesellschaft für Agrarökonomie 21(1): 3-12.

Heyder, M. and L. Theuvsen. 2012. Determinants and effects of corporate social responsibility in German agribusiness: a PLS model. Agribusiness 28(4): 400-428.

Hubbard, C. 2012. Do farm assurance schemes make a difference to animal welfare? Veterinary Record 170: $150-151$.

Huijps, K., H. Hogeveen, G. Antonides, N. Valeeva, T. Lam and A.G. Oude Lansink. 2010. Sub-optimal economic behavior with respect to mastitis management. European Review of Agricultural Economics 37(4): 553-568.

Jahn, G., M. Peupert and A. Spiller. 2003. Einstellungen deutscher Landwirte zum QS-System: Ergebnisse einer ersten Sondierungsstudie. Working paper, Institute of Agricultural Economics, University of Goettingen, Goettingen, Germany.

Janssen, J. and W. Laatz. 2007. Statistische Datenanalyse mit SPSS für Windows. Springer, Heidelberg, Germany.

Kayser, M. and A. Spiller 2011. Anspruchsgruppenmanagement für die Veredlungswirtschaft in Intensivregionen. In: Nachhaltige Tierproduktion in agrarischen Intensivgebieten Niedersachsens, edited by A. Veauthier and W. Windhorst. ISPA, Vechta, Germany, pp. 147-166.

Keeling, L., A. Evans, B. Forkmann and U. Kjærnes. 2013. Welfare Quality principles and criteria. In: Improving farm animal welfare: science and society working together: the Welfare Quality approach, edited by H. Blokhuis, M. Miele, I. Veissier and B. Jones. Wageningen Academic Publishers, Wageningen, the Netherlands, pp. 91-114.

Kjærnes, U., M. Miele and J. Roex. 2007. Attitudes of consumers, retailers and producers to farm animal welfare. Welfare Quality Report No. 2. Available at: http://www.welfarequality.net/media/1113/ wqr2.pdf.

Leach, K., H. Whay, C. Maggs, Z. Barker, E. Paul, A. Bell and D. Main. 2010. Working towards a reduction in cattle lameness: 1. understanding barriers to lameness control on dairy farms. Research in Veterinary Science 89: 311-317.

Luhmann, H., C. Schaper and L. Theuvsen. 2016. Future-oriented dairy farmers' willingness to participate in a sustainability standard: evidence from an empirical study in Germany. International Journal on Food System Dynamics 7(3): 243-257.

Lusk, J.L. and F.B. Norwood. 2012. Speciesism, altruism and the economics of animal welfare. European Review of Agricultural Economics 39(2): 189-212. 
Makatouni, A. 2002. What motivates consumers to buy organic food in the UK? British Food Journal 104 (3/4/5): 345-352.

Miele, M., H. Blokhuis, R. Bennett and B. Bock. 2013. Changes in farming and in stakeholder concern for animal welfare In: Improving farm animal welfare: science and society working together: the Welfare Quality approach, edited by H. Blokhuis, M. Miele, I. Veissier and B. Jones. Wageningen Academic Publishers, Wageningen, the Netherlands, pp. 19-48.

Miller, D. 1993. The architecture of simplicity. Academy of Management Review 18: 116-138.

Nocella, G., L. Hubbard and R. Scaroa. 2010. Farm animal welfare, consumer willingness to pay, and trust: results of a cross-national survey. Applied Economic Perspectives and Policy 32(2): 275-297.

Ritter, C., G.P.S. Kwong, R. Wolf, C. Pickel, M. Slomp, J. Flaig, S. Mason, C.L. Adams, D.F. Kelton, J. Jansen, J. De Buck and H.W. Barkema. 2015. Factors associated with participation of Alberta dairy farmers in a voluntary, management-based Johne's disease control program. Journal of Dairy Science 98: 7831-7845.

Schreiner, J.A. and U. Latacz-Lohmann. 2015. Farmers' valuation of incentives to produce genetically modified organism-free milk: Insights from a discrete choice experiment in Germany. Journal of Dairy Science 98: 7498-7509.

Skarstad, G.A., L. Terragni and H. Torjusen. 2007. Animal welfare according to Norwegian consumers and producers: definitions and implications. International Journal of Sociology of Agriculture and Food 15(3): 74-90.

Swinton, S.M., N. Rector, G.P. Robertson, C. Jolejole-Foreman and F. Lupi. 2015. Farmer decisions about adopting environmentally beneficial practices. In: The ecology of agricultural landscapes, edited by S.K. Hamilton, J.E. Doll and G.P. Robertson. Oxford University Press, NY, USA, pp. 340-359.

Valeeva, N.I., T.J.G.M. Lam and H. Hogeveen. 2007. Motivation of dairy farmers to improve mastitis management. Journal of Dairy Science 90: 4466-4477.

Vanhonacker, F., E. van Poucke, F. Tuyttens and W. Verbeke. 2010. Citizens' views on farm animal welfare and related information provision: exploratory insights from Flanders, Belgium. Journal of Agricultural and Environmental Ethics 23: 551-569.

Vanhonacker, F., W. Verbeke, E. van Poucke and F.A.M. Tuyttens. 2007. Segmentation based on consumers' perceived importance and attitude toward farm animal welfare. International Journal of Sociology of Agriculture and Food 15(3): 91-107.

Vetouli, T., V. Lund and B. Kaufmann. 2012. Farmers' attitude towards animal welfare aspects and their practice in organic dairy calf rearing: a case study in selected Nordic farms. Journal of Agricultural and Environmental Ethics 25(3): 349-364.

Weber, H., T. Rammsayer and J. Bengel. 2005. Handbuch der Persönlichkeitspsychologie. Hogrefe, Göttingen, Germany.

Weinrich, R., S. Kühl, A. Spiller and A. Zühlsdorf. 2014. Consumer attitudes in Germany towards different dairy housing systems and their implications for the marketing of pasture-raised milk. International Food and Agribusiness Management Review 17(4): 205-222.

Wissenschaftlicher Beirat Agrarpolitik BMEL (WBA). 2015. Wege zu einer gesellschaftlich akzeptierten Nutztierhaltung. Available at: http://tinyurl.com/yaxwuvcx.

Wolf, C.A., G.T. Tonsor, M.G.S. McKendree, D.U. Thomson and J.C. Swanson. 2016. Public and farmer perceptions of dairy cattle welfare in the United States. Journal of Dairy Sciences 99: 5892-5903. 